\title{
Introduction: Transregional and Regional Elites - Connecting the Early Islamic Empire
}

\section{The Project of the 'Early Islamic Empire at Work'}

Our knowledge about the working of the early Islamic Empire is still rather imbalanced. The caliphate ruled an expanse from Central Asia to North Africa for about 300 years until the 940 s, creating in the process a distinct civilization and culture. Research on the early Islamic Empire, and consequently our knowledge thereof, is still dominated by the perspective of the sources. Whilst unsurprising, the tendency of researchers to rely upon the viewpoint of the major historians of the Islamic Empire has led them to adopt the same geographical biases that these historians maintained. The most important of these is al-Ṭabarī (d. 923), who provides us with a monumental history of the world and the Islamic Empire until the time when its power was waning. As informative as al-Ṭabarì is, even about the far regions of the empire, his primary concern is the developments of its political and economic center, Greater Mesopotamia. This region, which comprised important metropolises such as al-Kūfa, al-Bașra, Wāsiț, Baghdād, Sāmarrā', and al-Mawșil, was tightly controlled and taxed. It also served as the power base of the Sasanians, an imperial tradition on which the Islamic Empire subsequently built. Historians have often transposed the information provided by al-Ṭabari and others regarding this economic, agricultural, and political heartland to the empire as a whole. It became the governing paradigm for the narrative of the empire.

The questioning of this assumption was the starting point of the European Research Council project 'The Early Islamic Empire at Work', which ran from April 2014 to September 2019. In investigating how the vast and diverse Islamic Empire was governed, the project critiques the reigning 'top-down' conceptualization, according to which the caliph and his court constitute the center from which imperial power, politics, and indeed history were transmitted. Instead, it posited a 'View from the Regions Toward the Center', which, inspired by scholars of European Medieval Studies such as Peter Thorau ${ }^{1}$ and Chris Wickham, ${ }^{2}$

1 Thorau 1998, 4-5

2 Wickham 2011.

๑ OpenAccess. (c) 2020 Stefan Heidemann, published by De Gruyter. (cc) BY-NC-ND This work is licensed under the Creative Commons Attribution-NonCommercial-NoDerivatives 4.0 License. 
connects regional histories to find coherence between imperial dynastic history and regional events. Five key regions were selected for the project, based on the diversity of their people, languages, religions and cultures, and history. These were Ifrīqiya, al-Shām (Syria), the Jazīra (Northern Mesopotamia), Fārs, and Khurāsān (eastern Iran). Through a combination of in-depth regional analyses and interregional comparisons, the project thus sought to explain the working of the early Islamic Empire from a regional perspective.

\section{The Question of Elites}

A key factor in understanding governance with regard to the early Islamic Empire are the various elites who were essential for the processes of regional integration and imperial cohesion. When acts of imperial governance are contextualized within the stream of regional and transregional events, against a backdrop of the movements of elites and individuals, the functioning of the empire within its legal and institutional framework becomes apparent, embedded in a network of reciprocal relations, dependencies, and permeations. These layers of imperial government, regional, and transregional activity, can then be synthesized into a comprehensive imperial history.

Relations between an empire and its subjected regions are never unilateral. No pre-modern empire could be ruled through the threat of military force alone. Significant sections of the provincial elites often consented to being part of an empire because of the advantages that it could provide, such as reliable communication and transportation lines, and an enforceable common legal framework. The regional elites were usually culturally, historically, socially, and economically rooted in their regions. Those who joined the empire's ranks were positioned between its demand for taxes and loyalty on the one hand, and the agricultural workforce, comprising the demographic majority in pre-modern societies, on the other. In every empire, the regions were burdened with taxes and other contributions to the maintenance of the central administration, its capital, courts, and military, and the privileges of the upper echelons of the regions and the imperial center. While the Islamic Empire seems to have been at the same time both bureaucratic, at least in its fiscal administration, and 'informal', meaning without any discernable formal 'Byzantine' hierarchy, the diversity of the regions and its elites entailed variations of governance, almost as a pattern. Practices differed from region to region, but so too did the resulting interactions with the elites in these regions.

The question of who constituted these elites, and the need to forge an operational terminology strong enough to analyze their identity and function, became 
a driving question at an early stage in the project. Rather than focusing on institutions, we pursued an actor-driven approach to understand the role played by persons (whether groups or individuals) and their networks in the Islamic Empire.

The elites we were most interested in are 'functional' elites. This category includes mainly political and economic elites who were crucial to the empire's stability. This still vague definition includes all administrative, and military elites, but also judicial elites. For questions of governance, the 'economic elites' mainly comprise the landholding elites. Although this group also includes the leaders of urban artisans and merchants, the sūqa and bay' $a$, and the long-distance merchants (tujjär), it was the landholding elites, a group which was often closely connected with the administration and the fisc, that were more relevant for our project. Old regional elites were often marked by their possession of land, and the new elites of the empire were investing their gains in landholding.

By design, the project's approach placed less emphasis on the importance of those elites who defined religion, religious-political ideology, and intellectual culture, such as theologians, and urban literates, although clerics and qāọiss who served in the regional administrations are included in the category of functional elites mentioned above.

The qualifier for functional elites is the terminological pair 'transregional' and 'regional'. The two terms comprise large and diverse groups which serve various functions, but they highlight mobility as a crucial trait of those elites. The term transregional refers to highly mobile elites operating across the empire and connecting its various regions. Examples of this category are governor families, military groups, legal scholars and other officials, as well as investors of large estates or long-distance merchants. Transregional elites and groups were vital for the maintenance of the Islamic Empire and for the creation of a specific imperial culture.

By contrast, regional elites tended to originate from the specific region in which they were active. It was in these regions where their influence was strongest. The regional elites rarely held leading positions in the caliphal administrative centers or at the caliph's court and it was the transregional rather than the regional elites who maintained the links between the court and the regions. The status of the regional elites often pre-dated the Islamic Empire and was based on various factors such as local military forces (e.g., Daylamites or Berbers), possession of strongholds, extended landholdings, or a position within religious hierarchies. Examples of such regional elites are the Sogdian nobility or high-ranking Christian clergy. The example of the Christian clergy, however, also underlines the potential for an intermediary group or a partial overlap between the two categories: bishops often studied outside their home regions but in 
Christian centers, appointments to different dioceses resulted in a high degree of mobility within the regions, and those who were elected as patriarchs not infrequently occupied positions of influence with the caliph.

As a rule, regional elites were stronger in places where the fiscal and administrative interest of the empire was clearly present, but not yet firmly established. The regional elite frequently took over judicial and tax-collecting functions, as Petra Sijpesteijn and Philip Wood show in their contributions to this volume. Other elites and groups within the regions were more loosely connected with the empire, or even opposed it. Examples include the Ibādīi Berbers in North Africa, nomad tribes, or old Iranian nobility in their own strongholds and castles.

A second look, however, offers an even more complex picture. Regional elites could evolve into transregional elites, such as the Sogdian nobility in the Iraqi centers. Vice versa, the founder of the Aghlabids, Ibrāhīm b. Aghlab, was a Khurāsānī Arab who grew up in Egypt and was evidently part of the transregional elite. During the war of succession between al-Amin and al-Ma'mūn (809-813) he built up an autonomous regional emirate in Ifrīqiya which his family ruled for generations, making them part of a regional elite. Similarly, the Arab garrisons of Fustāat in Egypt, originally a transregional military and elite group, underwent a process of 'regionalization' when the province was taken over by new Khurāsānian troops and their commanders.

Looking at the military, administrative, and political elites, we can distinguish fundamental shifts within the elite structure of the empire over time, a feature which sets the early Islamic Empire apart from its Roman and Sasanian predecessors. Every two to three generations, a new distinct class of elites took over the most important key positions. They each differed in terms of their geographical, ethnic, and social backgrounds. These new elites emerged largely by promotion and by privilege, from the top rather than by bottom-up social mobility or through revolutionary changes. This is most evident in the creation of the class of the administrators (kuttäb) or the Central Asian elite and 'bonded military' in the period following al-Mu'tașim billāh (r. 833-842).

The integration of the new elites into the administrative and military structures occurred through conversion to the privileged imperial religion, Islam. Islam as the religion of the empire had transcended ethnic privileges, but this did not preclude ethnic prejudices within the elite society (e.g., shu'übiyya), regional bonds, and/or power struggles between ethnically or regionally defined groups. The rise of the 'Abbāsids, for instance, was largely seen as the waning of the elite of the Arab conquerors and their descendants. Only the position of the caliph remained reserved for a member of Quraysh, or more specifically, a member of the 'Abbāsid family. 
Three major shifts in the structure of the military transregional elite can be observed. Under the Umayyads, the military consisted almost entirely of Muslim Arabs from the Arabian Peninsula and Syria who retained important governor positions, especially in Syria and Northern Mesopotamia, until the time of Hārūn al-Rashīd and al-Amīn (c. 660s to 820s). Between 750 and 820, they were gradually replaced by Khurāsānī amīrs and their armies, who took up key positions at the nodes of the empire. Among the Khurāsānians, Persianized Arabs and Arabized Iranians were almost indistinguishable from one another, due to the common Persian-Arab heritage that both shared. Between the $820 \mathrm{~s}$ and 860s, the Khurāsānians were replaced in key positions by Central Asians, Sogdians, Turkish nobility and bonded military (ghulāms or mamlūks), a shift initiated by al-Ma'mūn, al-Mu'tașim billāh, and al-Mutawakkil 'alā Allāh. The new Central Asian military elites and their armies were not only deployed in large garrison cities in the agglomerations of Baghdād, Sāmarrā', and al-Mutawakkiliyya, but were also stationed in key provinces such as Egypt.

These shifts, initiated from the top, occurred gradually rather than as a sudden disruption. This does not imply however, that the transitions from pre-Islamic to Islamic, from Arab to Khurāsānian to Central Asian elites were frictionless. They were often the backdrop of major rebellions, mainly orchestrated by those individuals or groups who saw their interests or status being threatened. Under certain circumstances they could - and did - mobilize support from the wider populace. Examples include the uprisings in Eastern $\operatorname{Iran}^{3}$ or in Egypt at the time of al-Ma'mūn.

The advantage of the use of the qualifiers 'transregional' and 'regional' over others - such as 'imperial', 'Muslim', 'religious', or 'administrative' - is that they are verifiable, and respond to the question of the integration of the regions into the wider empire. Prosopographical research into the careers of individuals and groups reveals their movements across the empire and/or their regional importance (see the contributions of Khan, Hagemann, and Gundelfinger/Verkinderen). A term such as 'imperial elites' can hardly be made operational; it may refer to entitlement and privilege granted by the caliphal administration, but it can describe either transregional or regional actors. Dionysius of Tall Mahrēe, for example, the West Syrian patriarch from c. 818-846, was a representative of the regional Jaziran elite, but cultivated close connections to the caliphal court, as Philip Wood shows. Appointments of qādīs from the regional elite, Hagemann shows, were also carried out by the caliph. The term 'transregional

3 Crone 2012. 
elites' avoids such difficulties and emphasizes an elite's function in the integration of the empire.

A terminological differentiation between 'Islamic' and 'non-Islamic' elites, such as Zoroastrian priests, Christian clergy, Jewish Geonim, and Buddhist leaders, would also not reveal much about their function within the empire. These groups include administrative, economic, intellectual, legal, and theological elites, but they were not static. Bishops, for example, fulfilled vital functions within the provinces: they dispensed justice and were involved in the taxation practices (see Wood and Sijpesteijn). Certain Muslim elites, on the other hand, were not involved in running the empire. On the contrary; the leaders of the predominantly anti-imperial Khārijites sometimes came from elite families or were former holders of positions in the imperial military.

The importance of understanding the role of elites becomes even more apparent when we look at how the provinces and regions functioned. Unlike studies of the Roman Empire, research on the Islamic Empire does not operate on an agreed concept of territoriality. The 'Early Islamic Empire' project generally questioned the concept of territoriality regarding the provinces of the empire. As Stuart Elden has argued, territoriality is the condition of being a territory, which is a "bounded space under the control of people, usually a state, [and] therefore is historically produced". It usually implies that the state can enforce its rules across its entire territory. ${ }^{4}$

Studies of the Roman Empire tend to use the concept of territoriality within a vision of empire based on the clear demarcation of provinces and dioceses under imperial control, expressed through established provincial borders that were often marked with boundary stones. Territoriality necessitates a very high level of control, suitable in a situation where a densely populated, continuous agricultural landscape had to be divided for administrative purposes such as tax collection or property rights on land. In the case of the early Islamic Empire, this form of territoriality is less evident and can only be reasonably assumed in densely populated areas, such as Greater Mesopotamia and perhaps Egypt. ${ }^{5}$ On the macro level, territoriality does not seem to have been a defining category for the provinces of the Islamic Empire, which covered almost all of the Old World Dry Belt, a mostly arid zone with oases, river and valley systems, and were mainly separated from each other by natural boundaries like steppes, deserts, mountain ridges, and large rivers. In Arabic geographic descriptions of the regions it is not boundaries which are marked, but roads and realms (al-masālik

4 For a broad discussion of the concept of territoriality, see Elden 2013, esp. 322.

5 For a comparison with the Sasanian Empire, see Payne 2017. 
wa-l-mamālik). ${ }^{6}$ For this reason, our research group laid less emphasis on territory as a basis for understanding administration and worked instead with a layered, but not necessarily hierarchical structure of authority within each province/region studied within the project.

The default concept of a province is a layered structure of transregional elites projecting and concentrating imperial power into a region, which is defined as a larger geographic entity. By virtue of the geographical setting, its people might have had a shared common history, religion, or language. This differs from an administrative concept of a province. The transregional elites functioned as conduits of imperial power. They were located in key cities that were often situated amidst a fertile, tax-rich agricultural hinterland. The projection of power was implemented through the governor and the deployment of garrisons of large transregional armies. Thus the provinces were formed mostly for the provisioning of state institutions, the administration, the military, and those transregional elites. A highly developed accounting system recorded in the caliphal administrative centers is evidence of tight control over those taxable areas. Where a governor could not subject sub-regions such as neighboring oases to his direct control, he appointed wālīs or 'ämils. Those areas or zones could still be quite closely connected to the provincial administration by taxation and military control. The junds in al-Shām or the Zāb in Ifrīqiya are such cases. Rebellions and uprisings against the governor testify to this tighter control, thus affirming the expanding power of the provincial administration within the region.

Outside these core regions, many forms of integration or co-optation of regional groups, nomads, mountain dwellers, and other regional populations existed. Numerous regional rulers, vassals at best and rebels at worst, nobilities, and self-governed communities were present across the imperial landscape. They often held onto their pre-Islamic positions and privileges, ruling large swathes of a region while its main cities were usually administered by Muslim governors. Examples are the Sogdian Bukhārkhōdās in the Bukhārā Oasis and the Ikhshīds in Samarqand. ${ }^{7}$ How exactly they shared power with the transregional elites should be analyzed on a case to case basis.

When direct taxation was not feasible, tribute from the vassal zone to the state coffers provided assurance of the former's commitment, whilst a gift from the governor could ensure the loyalty of an unpredictable local ruler. Jürgen

6 Brauer 1995.

7 See for example Kennedy 2010. 
Paul describes a layered structure for the Seljūq period and sees centralized taxation in money as a legacy of the 'Abbāsid administration. ${ }^{8}$

The autonomy of nomads and mountain dwellers was even more pronounced. The Berber Khārijites, who lived in the Atlas mountains, remained at the fringes of the administration and could be ignored at length. The same can be said for those living in mountain fortresses or in the steppes with their livestock. Pre-Islamic belief systems continued or even survived in these zones for long periods, but were transformed by the Islamic culture of the empire over time. These zones were hardly taxed if at all and often kept militarily at bay, but they lay within the commercial and cultural reach of the empire.

The task of the provincial governor was therefore to manage this layered structure of the region for the tax benefit of the empire rather than to impose the rule of the caliph in a defined territory. The regional elites played an important role in the management of the empire.

\section{The Conference and this Volume}

In order to explore the subject of elites and their role in imperial governance in more detail, the 'Early Islamic Empire' project held a conference on 7-8 October 2016 dedicated to 'Regional and Transregional Elites'. The conference sought to address a number of core issues such as, who were the various elites of a given region? How did these regional elites interact with the empire, what mechanisms and strategies did they employ, and (how) did they change in the course of interaction? How were transregional elites influenced by their interaction with regional elites, and how did they balance their relationships with both the latter and the central caliphal authorities? Where and how were transregional elites recruited, and was the shift from one such elite to another a sign of failure or were some elites 'simply' better at reproducing themselves? Which existing networks and emerging institutions helped elites to connect the empire and its diverse regions (e.g., tribal affiliations, family policies, strategic appointments, ecclesiastical hierarchies)?

It quickly became evident that the term 'elite' itself was used differently by the participants. The concluding roundtable discussion highlighted the lack of a terminology of elites common to our field as a whole, applicable irrespective of geographical or historical specificities, and with interdisciplinary relevance. The first chapter of the present volume picks up from this discussion and seeks to

8 Paul 2015. 
respond to the identified gap. "Studying Elites in Early Islamic History" by Hannah-Lena Hagemann, Katharina Mewes, and Peter Verkinderen explores the term elite and its conceptualization for the study of early Islamic history. In addition to reviewing the terminology used to refer to socially dominant groups in Arabic and Persian sources, Hagemann et al. also examine the development of 'elite studies' in the social sciences and related fields. In discussing its suitability for the field of Islamic Studies, they identify a number of problems that lead them to question the applicability of terms for socially dominant groups as defined in other disciplines to Islamic Studies.

Instead, the authors put forward their own working definition of 'elite' in an early Islamic context. They define elites "as individuals and groups of individuals who were in a position or had the potential to influence social, political, economic, and religious processes and decision-making in their communities." These people enjoyed an elevated (political, military, judicial, religious, and/ or economic) status that entitled them to power, wealth, influence, and other notable benefits. The status of elites depended on conceptions of merit, performance, ethnicity, ancestry, wealth, military prowess, religion, education, social capital, and other forms of privilege. These categories are entangled and can hardly be separated from each other, but predominant categories can often be discerned.

The case studies that follow are roughly organized according to geography, beginning with Arabia as the cradle of the empire and continuing with Iraq as the imperial center in the period most contributions focus on. These are followed by studies on regions of the Iranian east, which share a Sasanian past, followed by the Eastern Mediterranean and the north of the empire as former Byzantine territories with a strong Christian heritage. North Africa, with its Roman-Latin heritage, concludes the volume.

Most conference participants began with the assumption that their region forms a specific exception to the Greater Mesopotamian paradigm. However, the chapters of this volume reveal that it may in fact have been Greater Mesopotamia which formed the exception. The regions' geographical outlooks, their many cultures and religions, seemed at first to be too different to perceive any common ground for interregional comparisons and parallels; the sources differ for each region in scope, wealth of information, and emphasis. Despite the relationships and interactions between regional and transregional elites differing from region to region, however, the case studies in this volume exhibit certain common patterns in the case studies from North Africa to Khurāsān, for instance regarding the importance of informal governance structures or forms of social organization. 
Georg Leube, "Insult the Caliph, Marry al-Hasan, and Redeem Your Kingdom: Freiheitsgrade of Kindi Elites During the $7^{\text {th }}-9^{\text {th }}$ Centuries", investigates the regional networks of the Kinda tribe. Al-Ash'ath, a descendant of the kings of the South Arabian tribe of Kinda, was able to elevate his family to the highest echelons of the fledgling Islamic Empire through marriage ties. However, in a later stage, the significance of tribal networks was reduced to a regional level, at least in the case of the Kinda. His grandson, Ibn al-Ash'ath, attempted again to interfere in transregional affairs and led the revolt of the Iraqi tribes against 'Abd al-Malik. He mobilized the Iraqi milieu of pious Qur'ān readers ( $q u r r \bar{a}$ '), who were opposed to the state building efforts of the Islamic administration, for which Ibn al-Ash'ath used religious claims and downplayed his tribal affiliations.

Noëmie Lucas, “Landowners in Lower-Iraq During the $8^{\text {th }}$ Century: Types and Interplays”, analyzes social shifts in the landholding class of Lower Iraq. She defines a number of types of landowners, local Jews and Christians alongside Persian landowners (dahāqīn) and the new landed Islamic transregional elites investing in land. She looks into the advancing concentration of land in the hands of the latter in particular. These owners of large estates were often members of the Baghdādī elite and the 'Abbāsid family. Their growth was at the expense of small, local landowners. Her study also provides examples of transregional elites 'going regional', however.

Hugh Kennedy, "The Rise and Fall of the Early 'Abbāsid Political and Military Elite", shifts attention to the transregional military elites. He takes up the question of their changing origins and al-Manșūr's creation of the Khurāsānī military. He observes that in the early 'Abbāsid Empire, the inner core provinces, such as Iraq, the Jazīra, and Syria, remained reserved for members of the 'Abbāsid family, while the newly created class of quwwād went to the threatened frontiers of Ifrīqiya, Armīniya, and Khurāsān. Almost all of them came from Khurāsān, but not exclusively. As a transregional elite by imperial privilege close to the court, these men were geographically mobile, returning to Baghdād after their assignment, before again receiving new provincial appointments. Their status was almost hereditary. Their leaders, such as Khuzayma b. Khāzim, served their retainers as conduits of royal patronage and influence. This newly created 'Abbāsid elite of quwwād lasted at most three generations. Their dominance ended in the war of succession between al-Aminn and al-Ma'mūn in 813-814. Kennedy also takes up the case of the Kinda, whose leaders frequently served as governors of al-Kūfa under the 'Abbāsids, from Georg Leube.

Jürgen Paul, "Who Were the Mulūk Fārs?", returns to the discussion on landed regional elites, but from a different angle compared to Noëmie Lucas. He looks into a section of the elite that is usually difficult to pin down in the avail- 
able sources: local lords in Iran. Using al-Ișțakhrī’s discussion of the mulūk Fārs as a starting point, he lays out the characteristics of this class. As a case study, he presents the Arab family of Muhammad b. Wāṣil, who moved to Fārs in the late $7^{\text {th }}$ century and became part of the regional land-holding elite.

Ahmad Khan, “An Empire of Elites: Mobility in the Early Islamic Empire”, studies prosopographies pertaining to political and mostly transregional elites in order to examine patterns of social mobility, professional circulation, and structures of imperial rule in the 'Abbāsid Empire during the $8^{\text {th }}$ and $9^{\text {th }}$ centuries. He comes to an important conclusion hinting at seemingly contradictory patterns. At least in the cases that he analyzes, it can be seen that the early ' $\mathrm{Ab}$ bāsid empire was dominated by informal patterns of rule that depended disproportionately on personal retainers as well as governor and military families to maintain structures, while the empire appears as a bureaucratic centralized empire with regard to the fiscal administration.

Amikam Elad, "Preliminary Notes on the Term and Institution of al-Shākiriyya in Early Islam", addresses the problem of contemporary terminology for transregional military forces and elites in Arabic sources. He focuses on the case of the shäkiriyya. In a close examination of references pertaining to this military group in primary sources up to the reign of al-Ma'mūn, he challenges the current scholarship regarding this term. According to his interpretation, the term denotes different groups in varying contexts. Sometimes, it refers to a group of people with a military character, such as armed guards or a fighting force on the battlefield. In other contexts, no military connection is apparent, and the shäkiriyya in question appear to be simply servants or devoted followers. A certain link with Khurāsānī/Central Asian practices seems apparent, but Elad shows that both the institution and the meaning of its name could change when moved to another context.

Alison Vacca's contribution, "Khurāsānī and Transoxanian Ostikans of Early 'Abbāsid Armenia”, takes up some of the issues raised in Kennedy's study. With her entry, the volume enters a zone inhabited by a predominantly Christian population. Vacca uses Armenian and Arabic sources to analyze Armenia's multilayered provincial structure. The presence of Khurāsānī governors (ostikans) and troops in Armenia challenges the idea that Armenia was separated or isolated from developments in the Islamic Empire; on the contrary, Armenia was not infrequently the scene of conflicts between different segments of the Khurāsāni elite. A familiar pattern also emerges in her study of a layered structure of a provincial region and the (occasional) projection of power from the caliphal center via governors and garrisons.

Peter Verkinderen and Simon Gundelfinger's chapter, "Governors of the Early Islamic Empire - A Comparative Regional Perspective”, analyzes the ap- 
pointments of governors in Fārs and al-Shām on several levels until the reign of al-Mu'tamid 'alā Allāh (r. 870 - 892). Due to the lack of a distinct contemporary hierarchical terminology in the sources, these individuals were classified using the terms governor, super-governor, and sub-governor. By examining their backgrounds, Gundelfinger and Verkinderen identify appointment patterns, which differed clearly between Fārs and al-Shām. Al-Shām under the Umayyads was the seat of government, and its administration was presumably organized in the environment of the court, while Fārs was part of the super-province of alBașra. Appointment patterns changed over time, but they did not follow the periodization of Sufyānid, Zubayrid, Marwānid, early 'Abbāsid, or pre-Sāmarran and Sāmarran eras that is often applied to the empire as a whole. The authors discuss the tribal patterns of appointments of Arab governors in the Umayyad period, the involvement of Umayyad and 'Abbāsid family members in governing the provinces, and the decline of their influence towards the end of the period under study. The different patterns of appointments and the modes of governance, such as the super-provinces, display a common strategy for brief periods; more often policies were tailored according to the situation of the province. Their conclusions thus tie well into what Ahmad Khan calls informal structures of government.

Hannah-Lena Hagemann, "Muslim Elites in the Early Islamic Jazira: The Qāẹīs of Ḥarrān, al-Raqqa, and al-Mawșil”, looks into the local and regional networks of power within the province of al-Jazira during the Umayyad and early 'Abbāsid period. She also applies a prosopographical approach, focusing on the office of the $q \bar{a} d \underline{\imath}$ as an intersection of imperial and provincial authority. Using the cities of Harrān, al-Raqqa, and al-Mawșil as case studies, a comparative analysis of the individuals appointed to the qādīship reveals some commonalities in their backgrounds, but also clear differences in the appointment patterns. For example, the judges of Harrān formed part of the local elite, had a local power base, and were thus more independent from court patronage. In contrast, the qā elites. The judges of al-Mawșil, on the other hand, feature instances of appointments of local, regional, and transregional representatives. The variance was likely due to political and administrative factors in each of the cities and appears to have been a constant feature of the early Islamic period.

Philip Wood studies the "Christian Elite Networks in the Jazira, c.730 - 850". He looks at the same geographical area but focuses on a different group of elites. He uses Chris Wickham's definition of aristocracy as comprising individuals and groups possessing memory of ancestry, land, office, lifestyle, mutual recognition, and proximity to royal patronage to describe the episcopal and monastic networks of different denominations in the Jazīra. This Christian 'aristocratic' 
elite had its roots in the Roman Near East. Drawing on the information of the Chronicle of Michael the Syrian in particular, Wood argues that the caliphate became an increasingly hostile environment for Christian landed lay elites, incentivizing powerful families to take roles in the state's administration or within the church as bishops. Using examples from the Jacobite church, most famously Dionysius of Tall Mahrē, Wood argues that the state acted through the regional institutions of the church. It became increasingly involved in the governance of the church by publicly endorsing the patriarch and his ability to raise revenues from Christians, and also by supporting him against rival clerics. In the early 'Abbāsid period, the empire thus became involved in church matters as a part of its repertoire of governance.

Petra Sijpesteijn presents a similar case for Egypt, which shares a Roman Christian past and the perseverance of ecclesiastical networks with the Jazira. Her main argument relates to "Establishing Local Elite Authority in Egypt through Arbitration and Mediation”. She uses evidence from Arabic, Coptic, and Greek papyri to examine the role of individuals involved in mediation during the first four centuries following the Muslim conquest of Egypt. Her focus lies on the strategies of conflict resolution, the regional and transregional actors involved, and the question of whether these processes took place in an institutional framework or in a more informal environment. Sijpesteijn shows how these processes can inform us about changing power relations within the province. On a local level, arbitration and dispute resolution was sought from bishops, Muslim governors, and later qāḍīs alike. Hence, arbitration was to be found within a community, offering a strong alternative to a complicated and expensive Islamic legal system. Christian, Jewish, and Muslim community leaders continued to serve the needs of their specific constituencies. The authority inherent in conflict mediation itself created and affirmed local elite status. She discusses the changes in the composition of Egypt's elite, as they emerge from the analysis of local processes of conflict resolution, and how these changes can be connected to developments at the caliphal center.

Yaacov Lev, "The Civilian Ruling Elite of the Țūlūnid Ikhshīdid Period”, also looks at the situation in Egypt, but shifts the attention to different Muslim elites. His contribution is divided into two parts. In the first, Lev studies the terminology employed by the Arabic sources to refer to subjects and elite groups alike. Certain terms, such as șinf (pl. așnāf), firqa (pl. firaq), țā'ifa (pl. țawā'if), and țabaqa (pl. țibāq), appear to have applied to more or less distinct social groups, but on the whole the primary sources seem to have conceived of society as polarized between the general categories of khāșșa (elite) and 'āmma (commoners). In the second part, Lev examines the participation of the civilian elites of the Ikhshīdid period in the succession crises of 946 and 961. 
In his contribution, "Connecting the Ibādī Network in North Africa with the Empire ( $2^{\text {nd }} / 8^{\text {th }}-3^{\text {rd }} / 9^{\text {th }}$ Century)", Cyrille Aillet looks at a region which was one of the first to slip out of 'Abbāsid control during the war of succession between al-Amīn and al-Ma'mūn. At first sight, North African Ibāọism emerged during the Berber uprisings against Umayyad and 'Abbāsid rule and seemingly stayed at the margins of the empire. However, during the $8^{\text {th }}$ and $9^{\text {th }}$ centuries the civilian transregional elite of Ibādī merchants served as a conduit of imperial Islamic culture and the economy of the empire, albeit not of caliphal government. North African Ibādīis remained under the influence of their eastern strongholds, particularly al-Bașra, where the Ibāḍi elite was integrated into 'Abbāsid society. Al-Baṣra was an important emporium and Ibāḍī merchants circulated widely between the 'Abbāsid realm and its western fringes. Trans-Saharan trade, including slaves and gold, was presumably initiated by demand from within the empire, connecting the regional economies of North Africa with that of the imperial system. Intense scholarly exchange also linked west and east, thanks to intermediary meeting points such as Mecca, particularly during the hajj, and Fusțāt.

Some of the papers that were presented at the conference will be published in other venues, but contributed immensely to our discussion. Matthew Gordon and Luke Treadwell took contrasting attitudes towards the Sāmarran establishment. Matthew Gordon, in his talk on "Sāmarran Politics and the 'Abbāsid Provinces", set the career of Ahmad b. Țūlūn in the context of what he termed 'Sāmarran politics.' Ibn Ṭūlūn conducted himself very much in the manner of his peers in the Sāmarran military elite, at the heart of whose efforts lay twin goals: securing lucrative interests, including authority over appointments to Egypt, and maintaining an upper hand over the 'Abbāsid court in Sāmarrā'. As Gordon puts it: Ibn Ṭūlūn "overplayed his hand” trying to balance his interest in Sāmarrā' and in his own powerbase in Syria and Egypt, until he became an enemy of the all-powerful regent al-Muwaffaq and his successors.

Luke Treadwell's talk on "Mutțawwi'ī and Mamlūk: Military Elites in Sāmānid Central Asia and Beyond”, looked at the case of Ibn Ṭūlūn's contemporaries, the Sāmānids, a family that had already emerged as a regional elite in the 820, when al-Ma'mūn moved to Baghdād. In striking contrast to the Ṭūlūnids in Egypt, the Sāmānids never strove for caliphal patronage or positions at court, far from it: when they became actual rulers of Transoxania and Khurāsān, their geographical outlook differed tremendously from that of the 'Abbāsid Empire. They were focused northwards toward the steppes, and their commercial enterprise even reached via the Volga to the Baltic Sea. One reason for their seemingly atypical behavior might be that they were content with their status in the empire, viewing themselves almost as equals of the 'Abbāsids, without challenging their position in Baghdād nor 'stepping on their carpet' as clients. 


\section{What Remains to be Done?}

The roundtable discussion that followed the presentations highlighted the importance of studying the provinces of the empire individually and from a comparative perspective. Studying a particular province in isolation carries the risk of ignoring the effects of how developments in one province affected those in others, which can obscure broader patterns of imperial rule. An integrative approach promises insights into the structures and administration of the empire, especially as we deal with layered structures of authority in each province. This, in turn, brings into focus the role of elites and how their character and function varied from province to province.

Certain themes and patterns recurred in several papers and the ensuing discussions, but the discussion also gave rise to new questions, whilst others remain unanswered. Questions of group formation and the identity of elites (as regards ethnicity, military assignments, economic patterns, landowning, and religious affiliations) have yet to be addressed, as do further conceptual questions relating to territoriality and elite governance. We hope that the contributions in this volume will serve as a foundation on which further research can be based.

\section{Acknowledgements}

The research for this volume and its publication would not have been possible without the generous support of a European Research Council Advanced Grant. We owe gratitude to the anonymous reviewers of this project, who saw the potential in studying the 'View from the Regions Toward the Center'.

\section{Bibliography}

Brauer, Ralph W. (1995), "Boundaries and Frontiers in Medieval Muslim Geography”, Transactions of the American Philosophical Society, New Series 85, 6.

Crone, Patricia (2012), The Nativist Prophets of Early Islamic Iran. Rural Revolts and Local Zoroastrianism, Cambridge: Cambridge University Press.

Elden, Stuart (2013), The Birth of Territory, Chicago/London: Chicago University Press. Kennedy, Hugh (2010), “The Coming of Islam to Bukhara," in: Yasir Suleiman, ed., Living Islamic History: Studies in Honour of Professor Carole Hillenbrand, Edinburgh: Edinburgh University Press, 77-91. 
Paul, Jürgen (2015), 'Abbāsid Administrative Legacy in the Seljuq World, Working Paper Series of the ERC Project 'The Early Islamic Empire at Work - The View from the Regions Toward the Center', No 1, Hamburg.

Payne, Richard (2017), "Territorializing Iran in Late Antiquity: Autocracy, Aristocracy, and the Infrastructure of Empire," in: Clifford Ando and Seth Richardson, eds., Ancient States and Infrastructural Power. Europe, Asia and America, Philadelphia: University of Pennsylvania Press.

Thorau, Peter (1998), König Heinrich (VII.), Das Reich und die Territorien, Berlin: De Gruyter. Wickham, Chris (2011), “Tributary Empires: Late Rome and the Arab Caliphate," in: Peter Fibiger Bang and C. A. Bayly, eds., Tributary Empires in Global History, New York: Palgrave Macmillan. 